\title{
Trademarks and The Protection for Business Actors in Indonesia: Some Contemporary Issues and Problems
}

\author{
Nurul Fibrianti ${ }^{1 *}$ \\ ${ }^{1}$ Faculty of Law, Universitas Negeri Semarang, Indonesia \\ Corresponding Author: N. Fibrianti, email: nurulfibrianti@mail.unnes.ac.id
}

\begin{abstract}
The brand represents the identification to distinguish the results of the production of one business with other businesses, the brand is used as a product promotion tool, therefore the trademark is very important to protect the business. Through Law No. 20 of 2016, the state gives approval to all trademarks supported by businesses by requesting these trademarks. But only $4 \%$ of the number of SMEs that fulfill the trademark. Micro, small and medium business operators are not required trademarks because of their understanding and importance of trademarks, paid trademark registration and the complexity of the process and requirements for trademark registration are also additional supplements for SMEs. Therefore, there is a need for enhanced socialization of the importance of trademark registration and assistance with trademark registration.
\end{abstract}

Keywords: Trademarks, Protection of Business Actors, Intellectual property Rights, Small and Medium Enterprises (SMEs)

\section{How to cite:}

Fibrianti, N. (2020). Trademarks and The Protection for Business Actors in Indonesia: Some Contemporary Issues and Problems. Indonesian Journal of Advocacy and Legal Services, 2(1), 103110. https://doi.org/10.15294/ijals.v2i1.38040

\section{A. Introduction}

Food products processed by the home industry are types of products that are easily imitated and falsified by others because they are easy to produce, cheap raw materials and simple equipment. More food products released from home industries are done or made by micro and small entrepreneurs. It was they 


\section{N. Fibrianti}

who pioneered from the beginning (finding recipes, manufacturing processes, to providing their product names in this case commonly referred to as brands).

Brand is a term that is no longer displayed in the community. Every person who produces goods of their respective needs to give a name with the aim that their products can be known to the wider community.

In the realm of law, Intellectual Property Rights, brands have an important meaning, using identification tools to determine the results of production, effort, one another. Besides that, the brand can also be made a means of product promos, guaranteed the quality of goods and the origin of goods or services produced.

The brand is an intellectual property protected by the state. The arrangement is in Law No. 20 of 2016 concerning brands. Protection of trademarks by the state occurs if the trademark is registered at the Directorate General of Intellectual Property. Trademarks that have been registered as evidence for the holders of these marks and can also be used to ask others to distribute goods using that mark. Trademarks that have been registered must also be approved by Trademarks registered by other people with the same type of goods.

Based on field observations, many home industry processed food products are not registered trademarks even though the trademark will be given legal protection if it has been registered at the Directorate General of Intellectual Property. Business actors use the brand only as a symbol or just the name of the product to be known to the public or consumers. According to information from the Office of cooperatives and SMEs, until the end of June 2019 , the number of SMEs with new intellectual property was around 500700 business operators out of a total of 16,327 SMEs. Means only about $4 \%$ of the number of SMEs that register trademarks at the Directorate General of Intellectual Property.

Most businesses do not care about the trademark registration they have. They will feel a great need for the protection of their brand when their product is wellknown and the brand is then taken by someone else. In fact, the cost of resolving a trademark collateral case in court is more expensive than the registration fee of the mark.

Trademarks are not registered by business actors due to the business actor's ignorance of the benefits of trademark registration and the consequence of trademarks not being registered in addition to this because of the reason that trademark registration fees are considered expensive and registration procedures are discouraging. Even more alarming because businesses do not understand that the trademark owned must be registered in order to be given legal protection from the state. The assumption of SMEs 
is that trademark registration is not yet needed because SMEs capital is limited so that production and profit alone is enough. Though the principle of brand registration is first to file. That is, if there are the same trademarks registered by two parties, the party that first registered, the trademark owned by that party will be protected.

\section{B. Method}

This research is normative legal research, and all datas provided on this paper was obtained from offline and online medias, previous research, as well as project report. The paper only analyze the laws and regulation concerning to trademarks in the intellectual property rights law regime in Indonesia.

\section{Result and Discussion}

\section{Understanding the Brand}

Understanding Trademark according to Article 1 of Law Number 20 Year 2016 is a sign that can be displayed graphically in the form of images, logos, names, words, letters, numbers, color arrangement, in the form of 2 (two) dimensions and / or 3 (three) dimensions, sound, hologram, or a combination of 2 (two) or more of these elements to distinguish goods and / or services produced by persons or legal entities in the trading of goods and / or services.

A brand is required to have a distinguishing power because it is the distinguishing power that makes the brand known to the public because it is not the same between one brand with another on the same product.

\section{Type of Brand}

According to Trademark Law, there are 3 types of trademarks, namely: ${ }^{1}$

a. Trademark

Trademark is used on goods traded by a person / several people together or a legal entity to differentiate from other similar goods.

b. Service Mark

Trademarks are used for services traded by a person or persons jointly or a legal entity to distinguish them from other similar services.

c. Collective Brands

Trademarks are used on goods and / or services with the same characteristics regarding the nature, general characteristics, and quality

1 Law Number 20 of 2016 concerning Trademarks 


\section{N. Fibrianti}

of goods or services and their supervision which will be traded by several people or legal entities together to differentiate them from other similar goods and / or services.

\section{Brand Function}

The brand, which is a combination of the arrangement of images, names, words, letters, numbers, color arrangement is a peculiarity that has its own characteristics that distinguish it from other brands. The use of brands which incidentally has its own characteristics have functions including:

a. Identification to distinguish the results of production produced by a person or legal entity with the production of other people or other legal entities

b. As a means of promotion. Businesses can promote their products by only mentioning their brands

c. As a guarantee for the quality of the goods being marketed

d. Shows the origin of the item

From sharing the above functions, it can be concluded that the brand has a very important role in the business world that is as a builder of consumer loyalty. Consumers will be loyal to a product by remembering the name or brand of the product.

\section{Forms of Violation of the Trademark}

Brand violations occur because of the economic impulse to obtain maximum profits without going through sacrifice. Forms of violation against the brand can occur in the following ways:

a. The use of well-known brands without the permission of those who own the brands is an easy way to fake a product because of the phenomenon that exists today people become mainded label consumers. Regardless of the quality of a product, consumers will still choose products that have well-known trademarks. The prestige of using well-known products creates opportunities for producers to make the same products and brands by naming these products KW (quality) Super, KW 1, KW 2 and so on. Of course, these products are priced with slanted adjustments according to market segments. The large market demand for goods at low prices due to the prestige factor of well-known brands makes the proliferation of counterfeit products in the market.

b. Manufacturers also take advantage of the weaknesses of consumers who are less observant when buying a product by making products that have similar brands to well-known brands. The unpleasantness of consumers 
becomes an opportunity for these producers to do the harboring by making designs, color compositions, letters or numbers that are similar to well-known products in the hope that consumers will be fooled so that the products will sell well in the market.

This causes businesses who have painstakingly made quality products and built a good reputation in the community at a disadvantage. The desire to get big profits in a fast time without the need for a long process because they have been known to the public and already have customers is a major factor in the use of brands without permission, imitating famous brands with other terms, namely complementing.

For consumers, the brand is used to hold a choice of goods to be purchased and a symbol of self-esteem. So that there are brands that are well known by the public at large causing certain parties to want to be successful without a long struggle, the fastest way is to imitate or piggyback other people's brands. This has a detrimental effect on brand owners who are well known to the wider community. Consumers actually have been deceived by the imitation brand, which is clearly the quality of the product is not as good as the brand that is already known. If this happens then the competition is unfair competition. ${ }^{2}$

\section{Legal Protection}

Once the importance of the meaning of a brand causes the state to protect the intellectual property. Law number 20 of 2016 concerning trademarks regulates the protection of intellectual property rights in the form of trademark rights. The brand owner who has registered his brand will get exclusive protection from the state in a certain period in which the brand owner can use the brand for his own purposes or allow others to use it. The principle of protection for trademarks is first to file ie who first registers the trademark, then he is the one who gets protection. So if there are 2 of the same trademark that is registered by 2 different people then the person who will get protection is the first person to register.

The state can protect the rights to this mark by the owner applying for trademark registration. Trademark registration function:

a. As proof of ownership of the registered mark.

b. As a basis for rejecting the same mark registered by another party for similar goods or services.

2 Susilowati, Etty dalam Yustia Ayu Ratna Sari, Mieke. Passing Off dalam Pendaftaran Merek Kajian Putusan Mahkamah Agung Nomor 224 K/Pdt.Sus-HKI/2014. Jurnal Yudisial Vol. 7 No. 3 Desember 2014, p. 256 


\section{N. Fibrianti}

c. As a basis for prohibiting other parties from using the same mark on similar goods or services.

If the owner does not register the mark he has, the risk is that the mark can still be used by others, can still be used to promote the goods / services, the owner cannot prevent others from using the same mark.

A name of a product can be called a brand if it has enough power different from other brands. This means that the product name, symbol, logo that is used has the distinguishing power of other products so that the name is known to the public and the public can also differentiate from other brands even though the goods are similar.

Trademarks that have been registered are protected for 10 years, this protection period can be extended each time for the same period if the trademark owner proposes an extension.

Trademarks can also be transferred in several ways, namely through agreements such as licensing agreements so that other parties can use the mark with permission from the trademark owner. Heirs and wills can also be a cause for transferring registered marks. Or also with other reasons provided for in the legislation.

\section{Reasons for not registering a trademark}

The state has facilitated the protection of trademarks by making Law No. 20 of 2016 concerning Trademarks, but there are still many food product manufacturers that do not register the trademarks they own. The reasons entrepreneurs do not register their trademarks are various. This happens to small and micro level entrepreneurs because of the characteristics of small and micro entrepreneurs who are unfamiliar with the rule of law and the importance of a trademark and carelessness with the impact that will occur in the future.

The most important thing and become their main goal is to sell goods in the market and get the maximum profit. The problem is that the business will develop, the brand is known to the wider community, it can be franchised by giving licenses, and also the possibility that the brand will be accompanied by irresponsible people is unthinkable to them.

The trademark was not registered due to the small businessman's commonness on the urgency of trademark registration. Factors causing the trademark not to be registered by small and micro entrepreneurs include:

a. Lack of understanding of the manufacturer of the importance of registration of the trademark related to the functions and legal consequences if the mrek is not registered. 
b. Business actors do not understand that in order for trademarks owned to have legal protection so that irresponsible parties are used, registration of the mark must be carried out.

c. Procedure for trademark registration is considered complicated and requires inexpensive costs (because to see a trademark already owned by someone else or not yet required time and cost is not cheap)

Field observations were also carried out in other regions, namely in Kudus. Especially for producers of processed food home industry jenang holy, micro and small entrepreneurs only know that their products are requested for product permission at the Health Office so that they get the PIRT (Household Industry Food) label while the name of the product has included being registered at the Health Office. Their knowledge and understanding that trademarks must be registered with the Directorate General (IP) of the IPR Ministry of Justice and Human Rights and is a separate label separate from the PIRT label as a form of obtaining permission from the Health Office is not well socialized and well understood.

\section{Conclusion}

Behind the constraints that the author has stated, the benefits obtained from a registered trademark are greater than the time and costs incurred to register the mark. Therefore, it is necessary to socialize the importance of trademark registration and facilitation and assistance to small and micro entrepreneurs to register the trademarks they own. Because it requires announcing and understanding the characteristics possessed by small and micro entrepreneurs. Do not let the protection of trademarks provided by the state cannot be utilized by business actors because of ignorance of how to obtain protection for the brands they have.

\section{E. Acknowledgments}

Author would like to express the thakfullness to Faculty of Law, Universitas Negeri Semarang, especially to Indonesian Journal of Advocacy and Legal Services.

\section{F. Declaration of Conflicting Interests}

The authors state that there is no potential conflict of interest in the research, authorship, and/or publication of this article. 


\section{G. Funding}

None.

\section{H. References}

Fuady, M. (2005). Pengantar Hukum Bisnis: Menata Bisnis Modern di Era Global. Bandung: Citra Aditya Bakti.

Directorate General of Intellectual Property Rights Ministry of Law and Human Rights of the Republic of Indonesia, Intellectual Property Rights Guidebook

Soenandar, T. (1996). Perlindungan Hak Milik Intelektual di Negara-Negara ASEAN. Jakarta: Sinar Grafika.

Usman, R. (2003). Hukum Hak Atas Kekayaan Intelektual: Perlindungan dan Dimensi Hukumnya di Indopnesia. Bandung: PT. Alumni

Mieke, Y.A.R.S. (2014). Passing Off dalam Pendaftaran Merek Kajian Putusan Mahkamah Agung Nomor 224 K/Pdt.Sus-HKI/2014. Jurnal Yudisial 7(3), 255-272. http://dx.doi.org/10.29123/jy.v7i3.75

Law Number 20 of 2016 concerning Trademarks

Copyrights (C) 2020 by Auhtor(s). This work is licensed under a Creative Commons Attribution-NonCommercial-ShareAlike 4.0 International License. All writings published in this journal are personal views of the authors and do not represent the views of this journal and the author's affiliated institutions. 